\section{Closer ties in view for Soviet Union and India \\ Bangalore}

Closer scientific ties between India and the Soviet Union are being created in the follow-up to the long-term programme of cooperation signed by the Soviet General Secretary, Mikhail Gorbachev, and the Indian Prime Minister, Rajiv Gandhi, in July 1987. Eight areas have been named for potential collaboration, including space research and nuclear technology.

As a part of the agreement, a Soviet Proton booster will orbit an Indian-built Earth observation spacecraft, IRS-IA, early next year, and its successor, the IRSIB, in a few years time.

The Soviet Union has also agreed to loft an Indian-built microwave sensor payload on board a Soviet spacecraft sometime early next decade. More important, the Soviet leader has offered to set up a space research centre in India to help developing countries to obtain expertise.

Nuclear collaboration is proving more difficult. Controversy has arisen over the Soviet offer of a nuclear plant to India. The Soviet Union has been pressing India to throw open its nuclear facilities for inspection by the International Atomic Energy Authority. And although India's minister of state for science and technology has gone on record saying that India is actively considering the Soviet nuclear offer, there are others in India, including scientists and several engineering companies, who are suspicious that the offer may be an attempt to bridge the Soviet trade gap with India.

Many scientists are reluctant to proceed with nuclear power development that relies on foreign technology. Although eager to learn about uranium-enrichment technology, they feel that the best course for India would be to start off by building a low-level enrichment facility, relying on its own technology and facilities, rather than depending on an alien supplier, such as the Soviet Union, that would probably impose stringent conditions on the operation of any facility that it helped build.

Several Indian engineering companies, including Tata, L\&T and Walchandnager, have recently expanded their operations to meet the demand for India's nuclear power programme and are now worried that the Soviet entry into the Indian nuclear power programme would harm them.

Radhakrishna Rao

\section{Vienna Biozentrum: correction}

Rudolf Schweyen, head of the Institute of Microbiology and Genetics at the University of Vienna, is to be a senior faculty member of the Vienna Biozentrum (see Nature 330, 686; 1987). Erwin Wagner will join the Institute for Molecular Pathology.

\title{
Fears of recession complicate outlook in United States
}

Washington

Although the general health of the US scientific enterprise remains excellent, the events of 1987 made it clear that US scientists - and indeed all US society - can no longer afford to ignore the outside world. The stock market's tumble underscored the global interdependence of the US and other economies.

Congress now aims to support research that can help "economic competitiveness", a phrase that became fashionable in 1987 's grant applications and is likely to be worn by everyone in 1988. Justifying spending on pure science, especially on expensive items such as the Superconducting Super Collider (SSC), will be increasingly difficult.

The urgent need to trim the budget deficit may not require immediate sacrifices. So far, the Reagan administration and Congress have chosen to delay or slow down major new scientific projects, rather than eliminate them. Final decisions may well be postponed until the new administration takes over in 1989. But if the economy recovers, lost time can be made up.

Private universities weathered the crash of 1987 with the comfortable feeling that their losses were much smaller than the gains that they had chalked up earlier. In 1988 they may not be so fortunate. They, and others lacking massive federal support, will be most at risk should there be an economic downturn.

As economic forces will alter how research is conducted, so too the recently signed treaty eliminating intermediate and shorter-range nuclear missiles could signify a change for military research. Budgetary and political forces seem already to have stopped the Air Force's expensive and potentially destabilizing anti-satellite programme. But another potential victim of arms control, the Strategic Defense Initiative, seems destined to survive as President Reagan's pet project, even if Congress will not provide all the funds he would like.

The civilian space programme remains grounded as NASA (National Aeronautics and Space Administration) works towards returning the shuttle to operational status. Unhappily, problems with the latest shuttle motor test have caused a further postponement of flight resumption (see page 2). NASA is also pushing hard for its $\$ 14,000$ million manned space station, and the first round of contracts to build it have been awarded. But its high cost remains a liability.

The global effects of atmospheric pollution served as another example for the United States that unilateral action is not always the answer. International talks led to success last year in the signing of the Montreal Protocol to reduce ozonedestroying chemicals. By contrast, efforts to reduce pollutants causing acid rain are mired in nationalistic squabbling between the United States and Canada.

The debate over whether to build SSC, a $\$ 4,400$ million proton-proton collider, has become tangled in claims that it will produce innumerable technological spinoffs making it an investment in the country's future. But much of the clamour comes from states fighting to provide the site (see p.2). So far, the Department of Energy has moved forward on schedule: a shortlist of best-qualified sites has been released, with a selection in June.

The unexpected discovery of hightemperature superconductivity put some glamour back into science in 1987 , but commercial applications are a long way off. Those politicians who advocated the immediate and generous spending to bring the new superconductors to a state of industrial use are beginning to see for themselves that basic and applied research are not neatly divisible.

AIDS will continue to dominate biomedical research in 1988 . With an effective vaccine still far off, the focus will be on treatment and education. As the disease spreads, the strain on the healthcare and life-insurance systems will begin to show. Federal coordination of efforts to combat AIDS is likely to remain disjointed and ideologically driven, but federal money should continue to flow.

Biotechnology companies weathered the market buffeting well, although their high cash reserves and rock-bottom prices briefly made them attractive take-over targets. Despite the crash, biotechnology became profitable in 1987 with the approval of tissue plasminogen activator (TPA), the first biotechnology drug with a substantial market. But patent disputes continue to be a drain on resources. Negotiating the maze of regulations governing biotechnology will continue to put a strain on the industry, but environmental release experiments went forward last year despite critics, and gene therapy experiments may take place this year

A project to map and sequence the human genome has started, although whether it will be directed by a central authority remains uncertain. The scientific value of a complete sequence is unquestioned, but political support for the project may derive from fear that if the United States does not complete the sequence, the Japanese will.

Alun Anderson, Carol Ezzell, David Lindley \& Joseph Palca 